Article

Copyright () 2013
ISSN 20777019

Mycosphere Online Edition

Doi 10.5943/mycosphere/4/3/7

\title{
Myxomycete records from Eagle Hill in Maine
}

\section{Zoll $\mathbf{V}^{1}$ and Stephenson $\mathrm{SL}^{2}$}

${ }^{1} 5053$ Valley Stream Lane, Macungie, Pennsylvania 18062, vzoll@netzero.com
${ }^{2}$ Department of Biological Sciences, University of Arkansas, Fayetteville, Arkansas 72701, slsteph@uark.edu

Zoll V, Stephenson SL 2013 - Myxomycete records from Eagle Hill in Maine. Mycosphere 4(3), 520-527, Doi 10.5943/mycosphere/4/3/7

\begin{abstract}
Specimens of myxomycetes collected during the course of a week-long seminar held at approximately the same time during four different years (2004, 2006, 2008 and 2012) provide a baseline of data on the assemblage of species associated with the forests of one small area of Maine. Seventy-three species belonging to 29 genera were recorded during the four years, and 17 of these were collected in at least three different years. Sixty-one of the 73 species were represented by specimens that had fruited in the field under natural conditions, but these were supplemented by a number of specimens obtained from moist chamber cultures.
\end{abstract}

Key words - distribution - ecology - field collections - moist chamber cultures - plasmodial slime molds - spruce-fir forests

\section{Introduction}

The Eagle Hill Institute (formerly the Humboldt Field Research Institute) is located on the largely forested summit of Eagle Hill ( $\left.44^{\circ} 27^{\prime} 33^{\prime \prime} \mathrm{N}, 67^{\circ} 55^{\prime} 52^{\prime \prime} \mathrm{W}\right)$ on the eastern coast of Maine. Eagle Hill is the highest portion of Dyer Point, the peninsula that occurs between the Schoodic Point section of Acadia National Park and the Petit Manan National Wildlife Refuge. This region of Maine falls within the transition zone between northern boreal forests to the north and deciduous forests to the south. The forests present on the approximately 120 ha area of Dyer Point occupied by the Institute are predominantly coniferous, with red spruce (Picea rubens Sarg.) and balsam fir (Abies balsamea [L.] Mill.) the usual dominants. Broadleaf trees present include quaking aspen (Populus tremuloides Michx.), paper birch (Betula papyrifera Marsh.), red maple (Acer rubrum L.) and willow (Salix spp.).

Since 1987, the Eagle Hill Institute has offered a series of natural history seminars each year. During the period of 25-31 July in 2004, a week-long seminar on myxomycetes (plasmodial slime molds), taught by the second author, was offered. A similar seminar was offered again in 2006 (23-29 July) and 2008 (27 July-2 August). In 2012 (5-11 August), a seminar on both fungi and myxomycetes was offered, but unusually dry conditions limited the occurrence of the fruiting bodies of macrofungi and more emphasis was placed on myxomycetes than had been anticipated. Students enrolled in these four seminars collected specimens of myxomycetes in the forests at Eagle Hill, and a species list of field collections was compiled during each of the four years. The records represented by these specimens provide a set of baseline data on the myxomycete biota of the general study area as well as ecological information relating to the general abundance and 
frequency of occurrence of particular species. The objective of this paper is to summarize what is now known about the myxomycetes of this one small area of Maine.

\section{Materials and Methods}

The vast majority of the myxomycetes recorded for Eagle Hill are represented by specimens that fruited in the field under natural conditions, but some records were obtained with the use of the moist chamber culture technique described by Stephenson \& Stempen (1994). In the field, the opportunistic protocol described by Cannon \& Sutton (2004) was used to search for the fruiting bodies of myxomycetes. When myxomycete fruiting bodies were found, small portions of the substrate with the specimens present were glued onto pieces of paper placed in small pasteboard boxes and then allowed to dry out at room temperature. After this process, identification of particular specimens was carried out using standard monographs (e.g., Martin \& Alexopoulos 1969). During the seminar offered in 2004, a few samples of forest floor litter, aerial litter (dead but still attached portions of plants) and bark were collected at Eagle Hill and used to prepare a series of moist chamber cultures after the seminar had ended. Some additional samples were collected in some of the other years, but the number was much smaller than in 2004. Specimens obtained in moist chamber cultures were handled in the same fashion as described above for specimens collected in the field.

\section{Results}

A total of 73 species of myxomycetes representing 29 genera have been collected at Eagle Hill. Sixty-one of these are records derived from specimens collected in the field, whereas 12 species are known only from moist chamber cultures. In the list that follows, all species now known from Eagle Hill are arranged alphabetically by genus and then species. For species represented by specimens collected in the field, information is provided on the number of years (given in parentheses) each species was recorded along with comments on the geographical or ecological distribution of particularly noteworthy examples. Species known only from specimens appearing in moist chamber cultures are indicated by "mc" (also in parentheses). Nomenclature essentially follows Lado (2005-2013). Voucher specimens of the majority of the species reported herein are deposited in the herbarium of the University of Arkansas (UARK), with a few specimens in the personal herbarium of the first author. Data on the worldwide occurrence of rarely collected species were obtained from the Global Biodiversity Information Facility (http://www.gbif.org/), referred as GBIF throughout the remainder of this paper.

\section{Annotated List of Species}

Arcyria cinerea (Bull.) Pers. (4)

Comments - This is one of the most widespread and common of all myxomycetes, so it is not surprising that it was recorded all four years.

Arcyria denudata (L.) Wettst. (3)

Arcyria incarnata (Pers. ex J.F. Gmel.) Pers. (3)

Comments - Arcyria incarnata was the most common species of Arcyria at Eagle Hill.

Arcyria obvelata (Oeder) Onsberg (2)

Arcyria pomiformis (Leers) Rostaf. (3)

Ceratiomyxa fruticulosa (Müll.) T. Macbr. (4)

Comments - Evidence from recent molecular studies indicates that Ceratiomyxa fruticulosa is not a true myxomycete. However, it has almost always been included in taxonomic treatments of 
the group and this is the approach used herein. After a period of rainy weather, C. fruticulosa was often found to be exceedingly common on decaying logs and stumps.

Clastoderma pachypus Nann.-Bremek. (1)

Comments - The fruiting bodies of this comparatively rare species ( $<50$ records in GBIF) are so small that they are difficult to detect in the field, and most previous records appear to be from moist chamber cultures. However, it was collected from a decaying spruce stump in 2006.

Collaria arcyrionema (Rostaf.) Nann.-Bremek. ex Lado (3)

Collaria lurida (Lister) Nann.-Bremek. (mc)

Comments - Recorded in moist chamber culture on a sample of ground litter.

Comatricha elegans (Racib.) G. Lister (1)

Comatricha cf. laxa Rostaf. (1)

Comatricha nigra (Pers. ex J.F. Gmel.) Schröt. (3)

Comatricha pulchella (C. Bab.) Rostaf. (1)

Craterium minutum (Leers) Fr. (1)

Cribraria argillacea (Pers. ex J.F. Gmel.) Pers. (2)

Cribraria cancellata (Batsch) Nann.-Bremek. (4)

Cribraria intricata Schrad. (4)

Cribraria languescens Rex (1)

Cribraria macrocarpa Schrad. (2)

Cribraria microcarpa (Schrad.) Pers. (2)

Cribraria mirabilis (Rostaf.) Massee (1)

Cribraria oregana H.C. Gilbert (1)

Cribraria cf. rufa (Roth) Rostaf. (1)

Diacheopsis cf. insessa (G. Lister) Ing (1)

Comments - The collection referred to Diacheopsis insessa appeared to fit the description of this apparently rare species, for which $<20$ occurrences worldwide are listed on GBIF.

Diderma cinereum Morgan (1)

Didymium clavus (Alb. \& Schwein.) Rabenh. (1)

Didymium difforme (Pers.) Gray (mc) litter.

Comments - Recorded in moist chamber culture on samples of both ground litter and aerial 
Didymium iridis (Ditmar) Fr. (2)

Didymium melanospermum (Pers.) T. Macbr. (4)

Comments - This species often occurred in large fruitings on smaller pieces of coarse woody debris and associated forest floor litter and bryophytes.

Didymium minus (Lister) Morgan (1)

Didymium nigripes (Link) Fr. (2)

Didymium squamulosum (Alb. \& Schwein.) Fr. \& Palmquist (mc)

Comments - Recorded in moist chamber culture on samples of aerial litter.

Echinostelium minutum de Bary (mc)

Comments - Recorded in moist chamber culture on samples of red spruce bark.

Elaeomyxa cerifera (G. Lister) Hagelst. (1)

GBIF.

Comments - This is a species that is collected only rarely, with $<60$ occurrences listed on

Enerthenema papillatum (Pers.) Rostaf. (3)

Fuligo septica (L.) Wiggers (4)

Hemitrichia calyculata (Speg.) M.L. Farr (1)

Leocarpus fragilis (Dicks.) Rostaf. (2)

Licea biforis Morgan (mc)

Comments - Recorded in moist chamber culture on a sample of ground litter.

Licea minima Fr. (2)

Licea operculata (Wingate) G.W. Martin (1)

Comments - This species is usually recorded from moist chamber culture but was collected in the field in 2006.

Licea cf. variabilis Schrad. (1)

Lycogala epidendrum (L.) Fr. (3)

Metatrichia floriformis (Schwein.) Nann.-Bremek. (mc)

Metatrichia vesparia (Batsch) Nann.-Bremek. ex G.W. Martin \& Alexop. (2)

Paradiachea rispaudii (Hagelst.) Hertel ex H. Neubert, Nowotny \& K. Baumann (1)

Comments - This is a rather rare species, with $<50$ records on GBIF. The second author has collected it only twice in more than 30 years. Interestingly, both collections were associated with mosses on the forest floor.

Paradiacheopsis cf. solitaria (Nann.-Bremek.) Nann.-Bremek. (mc) 
Perichaena chrysosperma (Curr.) Lister (mc)

Comments - Recorded in moist chamber culture on a sample of aerial litter.

Perichaena depressa Lib. (mc)

Comments - Recorded in moist chamber culture on a sample of aerial litter.

Perichaena vermicularis (Schwein.) Rostaf. (mc) litter.

Comments - Recorded in moist chamber culture on samples of both aerial litter and ground

Physarum album (Bull.) Chevall. (1)

Physarum braunianum de Bary (2)

Physarum cinereum (Batsch) Pers. (mc)

Comments - Recorded in moist chamber culture on a sample of aerial litter.

Physarum confertum T. Macbr. (1)

Physarum globuliferum (Bull.) Pers. (3)

Physarum leucophaeum Fr. \& Palmquist (2)

Physarum psittacinum Ditmar (1)

Physarum virescens Ditmar (3)

Comments - In 2006, the bright yellow plasmodia and developing fruiting bodies of this species were exceedingly common at Eagle Hill, much more so than any other year. A least two dozen fruitings were observed in an area of no more than 0.1 ha in the general vicinity of the main buildings.

Physarum viride (Bull.) Pers. (3)

Reticularia splendens Morgan (1)

Stemonitis axifera (Bull.) T. Macbr. (3)

Stemonitis fusca Roth (2)

Stemonitis smithii T. Macbr. (1)

Stemonitis virginiensis Rex (1)

Stemonitopsis hyperopta (Meyl.) Nann.-Bremek. (1)

Stemonitopsis typhina (F.H. Wigg.) Nann.-Bremek. (1)

Symphytocarpus cf. flaccidus (Lister) Ing \& Nann.-Bremek. (1)

Trichia botrytis (J.F. Gmel.) Pers. (1) 
Trichia contorta (Ditmar) Rostaf. (2)

Trichia decipiens (Pers.) T. Macbr. (2)

Trichia favoginea (Batsch) Pers. (2)

Trichia subfusca Rex (mc)

Comments - Recorded in moist chamber culture on a sample of moss.

Tubifera ferruginosa (Batsch) J.F. Gmel. (1)

\section{Discussion}

Although all four seminars were held at approximately the same time of the year, some years appeared to be characterized by more favorable conditions for the fruiting of myxomycetes. For example, specimens were much more abundant in 2004 than in 2012, which can be attributed in part to the fact that 2012 was unusually dry. As noted in the list of species, six examples (Arcyria cinerea, Ceratiomyxa fruticulosa, Cribraria cancellata, C. intricata, Didymium melanospermum and Fuligo septica) were recorded every year, and eleven others (Arcyria denudata, A. incarnata, A. pomiformis, Collaria arcyrionema, Comatricha nigra, Enerthenema papillatum, Lycogala epidendrum, Physarum globuliferum, P. virescens, $P$. viride and Stemonitis axifera) were recorded in three of the four years. Clearly, these 17 species can be considered among the most characteristic members of the assemblage of myxomycetes associated with the forests of the general study area during late summer.

The records obtained for a number of rarely collected species certainly indicate that any comprehensive survey for myxomycetes at a particular locality needs to extend over a period of several years. Unfortunately, this is usually not the case, especially for localities in areas of the world that are not easily accessible. In most such localities, what is known about the myxomycete biota is often based on a single survey that extended over a relatively short period of time, sometimes less than a single day.

Because of their small size and the types of situations in which they occur, myxomycetes remain an understudied group of organisms (Stephenson 2011). This is particularly true for their patterns of occurrence in nature. As such, this paper represents a contribution towards a more complete understanding of their distribution and ecology in one type of forest ecosystem.

\section{Acknowledgements}

Appreciation is extended to all of the students who contributed to the data reported herein as a result of participating in the four seminars held at Eagle Hill.

\section{References}

Cannon P, Sutton B. 2004 - Microfungi on wood and plant debris. In: Biodiversity of Fungi: Inventory and Monitoring Methods. (eds G Mueller, G Bills, M Foster). Elsevier Academic Press, Burlington, Massachusetts 217-239.

Lado C. 2005-2013 - An online nomenclatural information system of Eumycetozoa. http://www.nomen.eumycetozoa.com accessed: 19.10. 2013.

Martin GW, Alexopoulos CJ. 1969 - The Myxomycetes. University of Iowa Press, Iowa City.

Stephenson SL. 2011 - From morphological to molecular: studies of myxomycetes since the publication of the Martin and Alexopoulos (1969) monograph. Fungal Diversity 50, 21-34.

Stephenson SL, Stempen H. 1994 -Myxomycetes: A Handbook of Slime Molds. Timber Press, Portland, Oregon. 